Review began 09/21/2021 Review ended 10/27/2021 Published 10/29/2021

\section{() Copyright 2021}

Adachi et al. This is an open access article distributed under the terms of the Creative Commons Attribution License CC-BY 4.0., which permits unrestricted use, distribution, and reproduction in any medium, provided the original author and source are credited.

\title{
A Case of Cast Nephropathy Found as the Cause of Severe Renal Failure
}

\author{
Gen Adachi $^{1}$, Naoto Mouri ${ }^{2}$, Ryuichi Ohta ${ }^{2}$, Chiak Sano ${ }^{1}$ \\ 1. Community Medicine Management, Shimane University Faculty of Medicine, Izumo, JPN 2. Community Care, Unnan \\ City Hospital, Unnan, JPN
}

Corresponding author: Gen Adachi, m161201@med.shimane-u.ac.jp

\begin{abstract}
Cast nephropathy is rare kidney disease with slow progression. It is associated with multiple myeloma (MM). In this study, we report a case of cast nephropathy in an 86-year-old woman who was previously independent in her activities of daily living (ADLs). However, she was found to have severe renal impairment after vomiting and a decrease in her ADLs. Blood and urine tests revealed the renal disorder. The patient was immediately treated with hemodiafiltration. IgG, IgA, and IgM levels were decreased by immunoelectrophoresis. A kidney biopsy showed crystals and periodic acid-Schiff stain (PAS)-negative urinary casts in the tubules. Bence Jones protein-lambda type M protein was detected in the urine. The patient was diagnosed with cast nephropathy due to MM. Hemodialysis was continued. The patient's family and the patient did not wish to initiate chemotherapy. The decision was made to follow the patient's progress. In this case, a patient who was originally independent in her ADLs developed severe renal failure with an acute course. This case suggests the importance of differentiating MM based on renal failure, even if the presentation is not typical, as elderly patients may have an atypical presentation of the disease, which can avoid invasive procedures such as renal biopsy.
\end{abstract}

Categories: Internal Medicine, Nephrology, Hematology

Keywords: geriatrics, renal biopsy, renal failure, multiple myeloma, cast nephropathy

\section{Introduction}

Cast nephropathy is a rare renal disorder caused by tubulointerstitial lesions in patients with multiple myeloma (MM). It is caused by an excessive increase in monoclonal immunoglobulin light chains. These flow into Henle's loop, bind to the Tamm-Horsfall protein, and form urinary casts that obstruct the ascending limb of Henle's loop and the distal tubule. As a result, the pressure in the renal tubules (Bowman's capsule) increases, resulting in a decrease in the glomerular filtration rate (GFR) and a decline in renal function [1]. Progression from asymptomatic myeloma to symptomatic myeloma or systemic amyloidosis occurs at a rate of $10 \%$ per year for the first five years after diagnosis, $3 \%$ per year for the next five years, and $1 \%$ per year after 10 years (median of approximately 2 years) [2]. In addition, overall survival correlates significantly with the highest eGFR, with a hazard ratio of 1.6 for every $15 \mathrm{ml} / \mathrm{min} / 1.73 \mathrm{~m}^{2}$ of estimated GFR (eGFR) below $45 \mathrm{ml} / \mathrm{min} / 1.73 \mathrm{~m}^{2}$, as shown by a retrospective study [3]. In general, the course of cast nephropathy is considered to be gradual. The diagnosis of MM or primary amyloidosis often precedes the onset of renal failure, followed by progression to end-stage renal failure. However, it has been emphasized that crystalline casts of immunoglobulin light chains are rarely observed and can cause acute exacerbation. In this study, we encountered a case of cast nephropathy in which crystalline casts were observed. The patient was found to have a severe renal disorder at the time of admission. Not only was this a rare presentation, but it was also a case of acute renal failure in an 86-year-old patient. This condition necessitated a discussion regarding the extent of scrutiny going forward. Therefore, we report this case, as it may suggest the importance of considering cast nephropathy caused by MM as one of the differential diagnoses of advanced renal failure among older patients.

\section{Case Presentation}

An 86-year-old woman was admitted to our hospital with a chief complaint of fatigue and acute renal failure. She was scheduled to be admitted to the orthopedic department for pain control of lumbar spinal canal stenosis. However, she vomited once in the morning a week before presentation and was unable to bathe without assistance two days prior to admission. Blood tests revealed severe renal impairment. The patient was referred to the department of internal medicine for consultation on the day of admission. This patient's medical history included medial osteoarthritis of the left knee, lumbar spinal canal stenosis, and an L2 vertebral fracture two years before admission. There were no malignant findings. She was followed by her general practitioner for blood tests every six months. Her creatinine was $0.64 \mathrm{mg} / \mathrm{dL}$ eight months prior to the hospital visit and $1.14 \mathrm{mg} / \mathrm{dL}$ one month prior to the hospital admission with no further investigation. Her vital statistics were as follows: height $142 \mathrm{~cm}$, weight $41.8 \mathrm{~kg}$; blood pressure 145/76 $\mathrm{mmHg}$, pulse rate 74 beats/min, body temperature $36.4^{\circ} \mathrm{C}$, respiratory rate 16 breaths/min, and oxygen saturation (SpO2) $98 \%$. Blood tests revealed severe renal dysfunction with the following levels: blood urea nitrogen $139.9 \mathrm{mg} / \mathrm{dL}$, 


\section{Cureus}

creatinine $16.81 \mathrm{mg} / \mathrm{dL}$, Na $134 \mathrm{mEq} / \mathrm{l}, \mathrm{K} 7.5 \mathrm{mEq} / \mathrm{l}, \mathrm{Cl} 100 \mathrm{mEq} / \mathrm{l}$, Ca $8.1 \mathrm{mg} / \mathrm{dL}, \mathrm{P} 11.4 \mathrm{mg} / \mathrm{dL}$, and erythrocyte sedimentation rate (ESR) $101 \mathrm{~mm}$ /hour. Urinalysis showed white blood cells (2+), protein $\left(2^{+}\right)$, occult blood (1+), and granular and waxy casts in the urine sediments on the fourth day of admission (Tables 1-2). Blood gas tests revealed the following: $\mathrm{pH} 7.146$, partial pressure of carbon dioxide (PCO2) $21.6 \mathrm{mmHg}$, bicarbonate (HCO3) $7.2 \mathrm{mmol} / \mathrm{L}, \mathrm{cK}+7.5 \mathrm{mmol} / \mathrm{L}$, cLac $0.4 \mathrm{mmol} / \mathrm{L}$, and AnGap $16.9 \mathrm{mmol} / \mathrm{L}$. The lab tests indicated metabolic acidosis with an enlarged anion gap.

\begin{tabular}{|c|c|c|}
\hline Marker & Level & Reference \\
\hline White blood cell & 8.7 & $3.5-9.1 \times 10^{\wedge} 3 / \mu$ \\
\hline Red blood cell & 3.03 & $3.76-5.50 \times 10^{\wedge} 6 / \mu$ \\
\hline Hemoglobin & 9.5 & $11.3-15.2 \mathrm{~g} / \mathrm{dL}$ \\
\hline Hematocrit & 28.7 & $33.4-44.9$ \\
\hline MCV (Mean corpuscular volume) & 94.9 & $79.0-100.0 \mathrm{fl}$ \\
\hline MCH (Mean corpuscular hemoglobin) & 31.4 & 26.3-34.3 pg \\
\hline MCHC (Mean corpuscular hemoglobin concentration) & 33.1 & $30.7-36.6 \mathrm{~g} / \mathrm{dL}$ \\
\hline RDW (Red blood cell distribution width) & 13.1 & $0.2-1.2 \square$ \\
\hline Platelet & 10.9 & $13.0-36.9 \times 10^{\wedge} 4 / \mu$ \\
\hline Neutrophil & 90.2 & $44.0-72.0 \square$ \\
\hline Lymphocyte & $6 / 8$ & $18.0-59.0 \square$ \\
\hline Monocyte & 2.6 & $0.0-12.0 \square$ \\
\hline Eosinophil & 0 & $0.0-10.0 \square$ \\
\hline Basophil & 0.4 & $0.0-3.0 \square$ \\
\hline Total bilirubin & 0.3 & $0.2-1.2 \mathrm{mg} / \mathrm{dL}$ \\
\hline Direct bilirubin & 0.1 & $<0.3 \mathrm{mg} / \mathrm{dL}$ \\
\hline AST (Aspartate aminotransferase) & 10 & 8-38 IU/I \\
\hline ALT (Alanine aminotransferase) & 15 & 4-43 IU/I \\
\hline ALP (Alkaline phosphatase) & 107 & $106-322$ U/L \\
\hline LAP (leucine aminopeptidase) & 55 & 80-160 IU/I \\
\hline Y-GTP (Y-glutamyl transpeptidase) & 26 & $<48 \mathrm{IU} / \mathrm{I}$ \\
\hline Cholinesterase & 278 & 201-421 IU/I \\
\hline LDH (Lactate dehydrogenase) & 237 & $121-245 \mathrm{U} / \mathrm{L}$ \\
\hline ZTT (Zinktrübungstest) & 0.7 & $2-12$ K.U \\
\hline Total protein & 7.5 & $6.5-8.3 \mathrm{~g} / \mathrm{dL}$ \\
\hline Albumin & 3.7 & $3.8-5.3 \mathrm{~g} / \mathrm{dL}$ \\
\hline Amylase & 270 & 44-132 IU/I \\
\hline Blood sugar & 81 & $60-109 \mathrm{mg} / \mathrm{dL}$ \\
\hline Total cholesterol & 166 & $130-219$ mg/dL \\
\hline Uric acid & $6 / 6$ & $2.3-7.0 \mathrm{mg} / \mathrm{dL}$ \\
\hline BUN (Blood urea nitrogen) & 139.9 & $8-20 \mathrm{mg} / \mathrm{dL}$ \\
\hline Creatinine & 16.81 & $0.47-0.49 \mathrm{mg} / \mathrm{dL}$ \\
\hline Serum $\mathrm{Na}$ & 134 & 135-150 mEq/l \\
\hline Serum K & 7.5 & $3.5-5.3 \mathrm{mEq} / \mathrm{l}$ \\
\hline
\end{tabular}




\section{Cureus}

$\begin{array}{lll}\text { Serum Cl } & 100 & 98-110 \mathrm{mEq} / \mathrm{l} \\ \text { Serum Ca } & 8.1 & 3.5-5.3 \mathrm{mg} / \mathrm{dL} \\ \text { Serum P } & 11.4 & 0.2-1.2 \mathrm{mg} / \mathrm{dL} \\ \text { CK (Creatine kinase) } & 134 & 41-153 \mathrm{U} / \mathrm{L} \\ \text { CRP (C-reactive protein) } & 0.45 & <0.3 \mathrm{mg} / \mathrm{dL} \\ \text { eGFR (Estimated glomerular filtration rate) } & 1.8 & <60.0 \mathrm{ml} / \mathrm{min} / 1 \\ \text { Prothrombin time } & 136.7 & 70-140 \square \\ \text { PT-INR (Prothrombin time-international normalized ratio) } & 0.86 & 0.80-1.20 \\ \text { APTT (Activated partial thromboplastin time) } & 25.9 & 23-40 \mathrm{sec} \\ \text { Treponema pallidum antibody } & 0.02 & <0.5 \mathrm{~S} / \mathrm{CO} \\ \text { Hepatitis B surface antigen } & 0 & <0,05 \mathrm{IU} / \mathrm{mL} \\ \text { Hepatitis C virus antibody } & 0.03 & <1.0 \mathrm{~S} / \mathrm{CO} \\ \text { BNP (Brain natriuretic peptide) } & 34.5 & <18.4 \mathrm{pg} / \mathrm{ml}\end{array}$

\section{TABLE 1: Laboratory values of the patient (Day 1)}

\begin{tabular}{|l|l|l|}
\hline White blood cell & Day 1 & Day 4 \\
Nitrite & $(2+)$ & $(3+)$ \\
Protein & $(-)$ & $(-)$ \\
Sugar & $(2+)$ & $(1+)$ \\
Bilirubin & $(-)$ & $(-)$ \\
Ketone bodies & $(-)$ & $(-)$ \\
Occult blood & $(-)$ & $(-)$ \\
Red blood cell & $(1+)$ & $(3+)$ \\
White blood cell & & $>50 / \mathrm{HPF}$ (high power field) \\
Squamous epithelial cells & & $>50 / \mathrm{HPF}$ \\
\hline Granular casts & & $<1 / \mathrm{HPF}$ \\
Waxy casts & $3-9 / 10 \mathrm{LPF}$ (low power field) \\
Protein amount & $3-9 / 10 \mathrm{LPF}$ \\
Estimated daily protein amount & $106 \mathrm{mg} / \mathrm{dL}$ \\
\hline
\end{tabular}

TABLE 2: Urine test

Emergency hemodialysis with a right internal jugular vein catheter was initiated on the second day of admission. Considering further rapid progression, steroids were urgently administered on the third day of admission due to suspicion of antineutrophil cytoplasmic antibody (ANCA)-associated glomerulonephropathy. This was performed prior to a bone marrow biopsy and immunofixation electrophoresis. Considering renal atrophy and renal damage due to malignancy, an abdominal CT, head MRI, and upper gastrointestinal endoscopy were performed. However, there was no renal atrophy, and no obvious malignant findings were observed (Figure 1). Additional tests for antinuclear antibody, antistreptolysin 0 antibody, anti-glomerular basement membrane antibody, and anticardiolipin antibody were all normal. The serum immunoelectrophoresis that we had submitted on the second day of admission came 


\section{Cureus}

back on the eighth day, and the IgG, IgA, and IgM had decreased. On the twentieth day of admission, a renal biopsy of the right kidney was performed. Crystals in the tubules and periodic acid-Schiff (PAS)-negative urinary casts suggested acute kidney injury associated with cast nephropathy (Figures 2-3). Additional investigations were performed to determine the cause of the cast nephropathy. On the 33rd day of admission, Bence-Jones protein- $\lambda$ M protein was detected in the urine. And IgD- $\lambda$ M protein and BenceJones protein- $\lambda$ protein were detected on the 36 th day (Figure 4). Additional blood data showed a $\lambda$ type free light chain of $8440 \mathrm{mg} / \mathrm{L}$ ( $\mathrm{K} / \lambda$ ratio of $<0.001$ ). This indicated light chain MM or monoclonal gammaglobulinemia (MGRS). Bone marrow examination showed scattered plasma cell nests of $23 \%$, which was consistent with MM (Figure 5). Finally, the patient was diagnosed with IgD- $\lambda$ type MM. There were indications for treatment. However, based on a discussion with a hematologist, it was concluded that active treatment for myeloma would not improve the patient's condition. This patient was bedridden and her condition was poor. The side effects of the treatment could have impinged on her appetite and condition. When we discussed this with the patient, she refused to undergo chemotherapy or further active treatment. As a result of this discussion, we decided to treat her with palliative measures. For the anemia, we employed a blood transfusion and a darbepoetin alfa injection. Maintenance dialysis was initiated for the chronic renal failure. As it was difficult for the patient to return home, she was admitted to a nursing care facility.

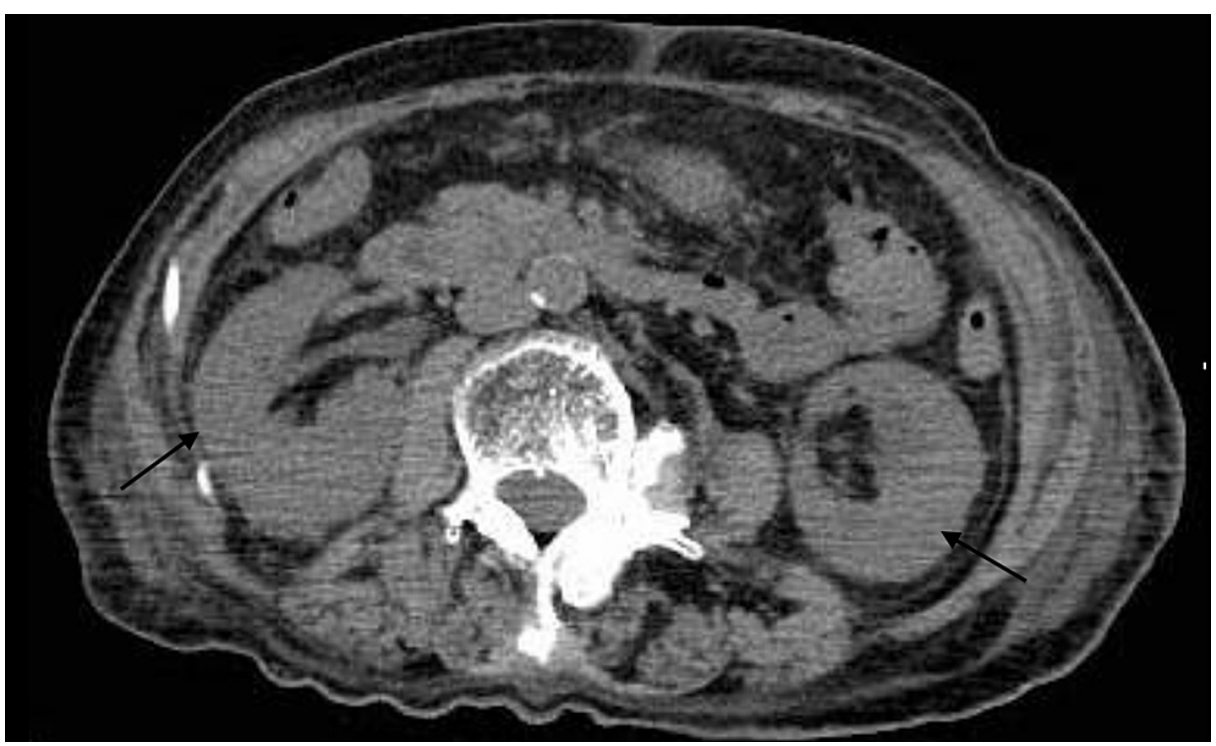

\section{FIGURE 1: Abdominal CT}

There is no obvious renal atrophy. 


\section{Cureus}

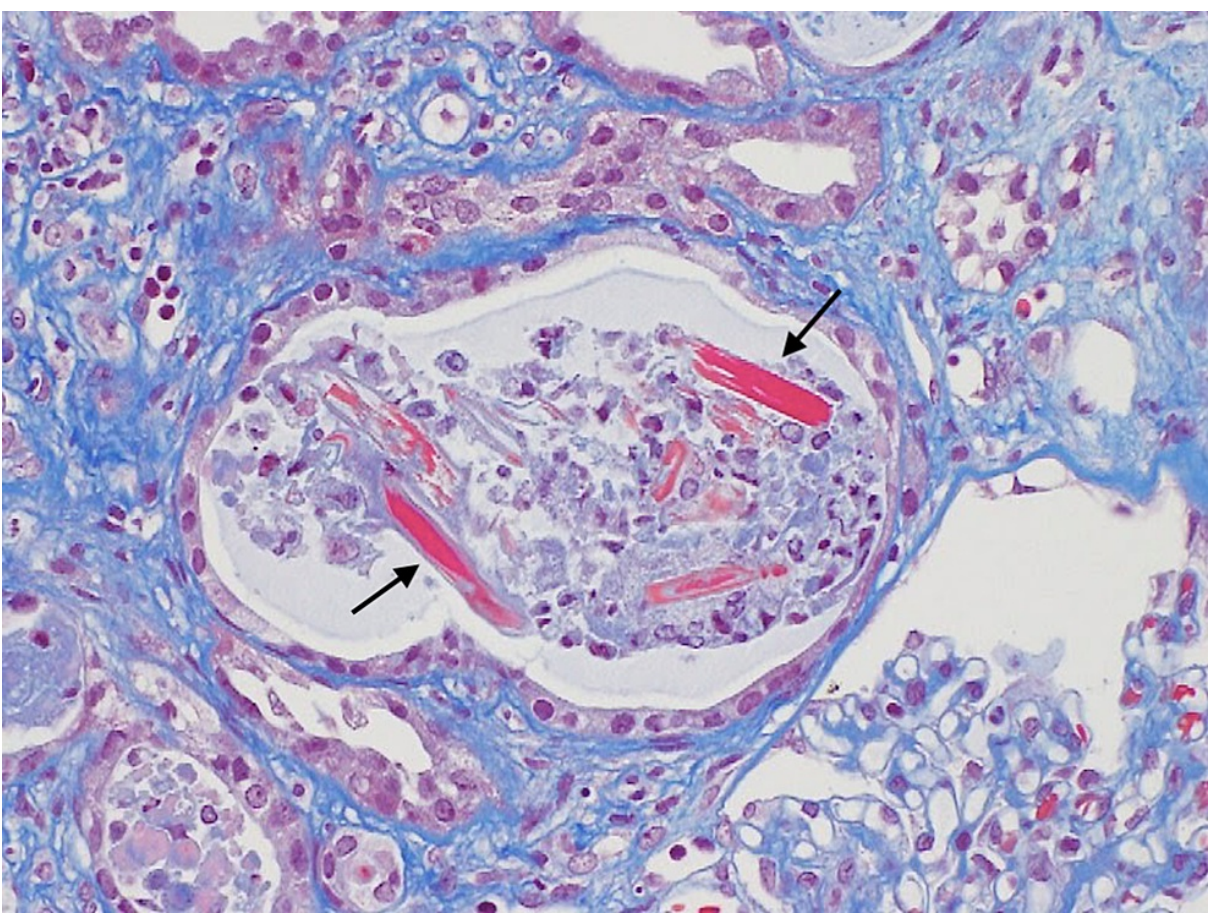

FIGURE 2: Masson staining for renal biopsy

Crystalline structures with a reddish stain can be seen in tubules.

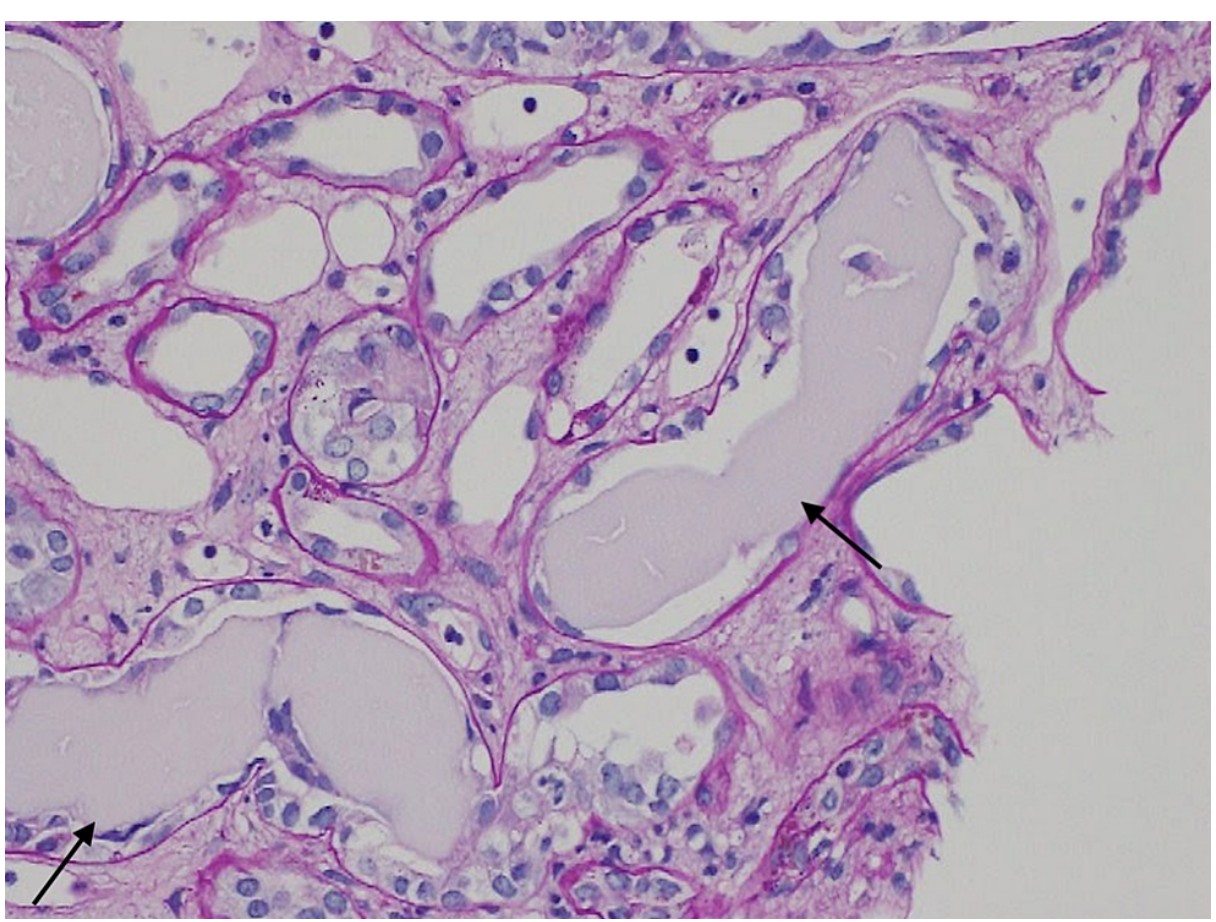

FIGURE 3: PAS stain for renal biopsy

PAS-negative urinary casts can be seen.

PAS: periodic acid-Schiff 


\section{Cureus}

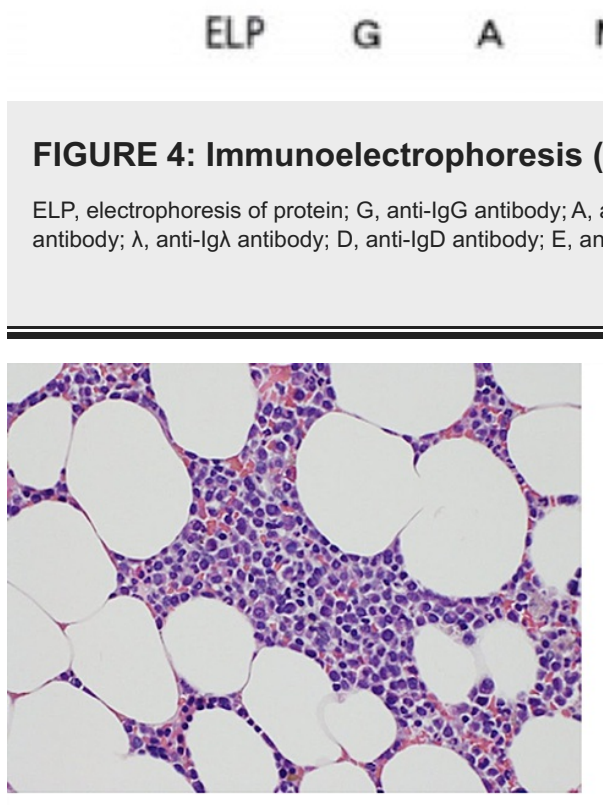

M $\quad \kappa \quad \lambda$

D E

\section{FIGURE 4: Immunoelectrophoresis (specific antiserum)}

ELP, electrophoresis of protein; $\mathrm{G}$, anti-IgG antibody; A, anti-IgA antibody; M, anti-lgM antibody; $\mathrm{K}$, anti-Igk antibody; $\lambda$, anti-Ig $\lambda$ antibody; D, anti-IgD antibody; $E$, anti-IgE antibody; IgD-lambda M protein is observed

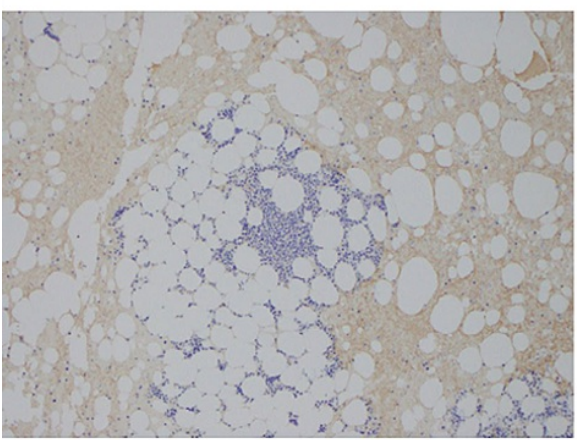

C

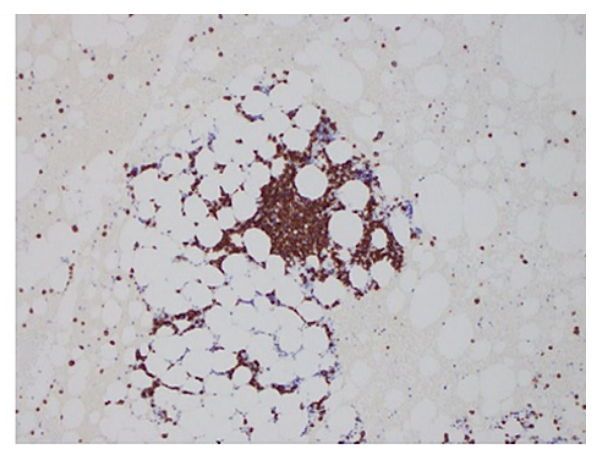

b

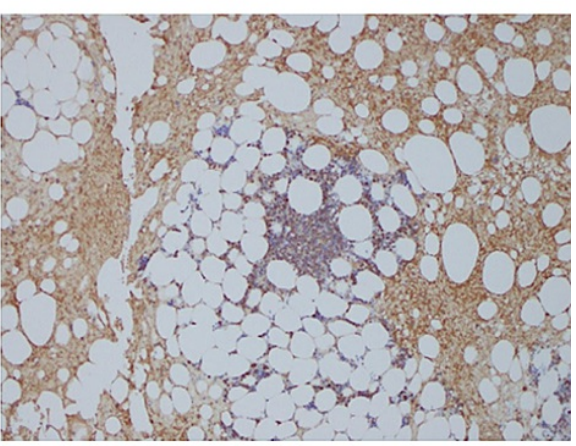

d

FIGURE 5: Bone marrow biopsy

a. Hematoxylin-eosin stain, b. CD138 stain, c. Kappa stain, d. Lambda stain

\section{Discussion}

Herein, we report a case of cast nephropathy caused by IgD-type MM. The cause of severe renal failure was found incidentally in an 86-year-old patient who came to the hospital with a complaint of back pain. Although cast nephropathy generally has a slow course, in this case, we considered the possibility of renal damage due to systemic disease. The patient was found to be in a severe state and was of advanced years. A renal biopsy was performed and a precise diagnosis of cast nephropathy due to MM was made. Normally, the starting point to suspecting MM is hypercalcemia and the gap between serum total protein and albumin. The flow of diagnosis for MM is to identify M-protein by serum protein fractionation and serum/urine protein electrophoresis and to confirm the diagnosis by bone marrow puncture. However, in this case, due to the 
atypical presentation of no hypercalcemia, high serum total protein, and low albumin, the first step was to discover cast nephropathy by renal biopsy.

A renal biopsy has been reported to reveal the diagnosis in $15-33 \%$ of patients aged $60-65$ years and older [47]. This suggests that a renal biopsy may provide valuable diagnostic and prognostic data even in patients aged 80 years and older [8]. Dehydration, medication, nephrosclerosis, diabetic nephropathy, chronic glomerulonephritis, and ureteral stones have been suggested as probable causes of renal failure in older patients. However, when focusing on renal failure, the possibility of IgA and other immune-mediated glomerulonephritis, as well as associated nephrotic syndrome and vasculitis, makes a diagnosis by renal biopsy essential [9]. Physiological atrophy of the kidneys and shrinkage of the renal parenchyma due to aging makes renal biopsy difficult. It has been reported that complications from a renal biopsy performed with appropriate techniques are not more common in older patients than in younger patients [10]. It should be considered in Japan, where older patients are increasingly being treated in clinical practice [11-12]. In a questionnaire survey of 168 facilities in Japan, 57\% of the respondents were between 80 and 89 years of age, and $14 \%$ were 90 years of age or older. This is the maximum age to consider a kidney biopsy. In other words, approximately $30 \%$ of hospitals do not consider a kidney biopsy for patients in their 80s or older in Japan [13]. Ageism should not prevent renal biopsy when it is useful, and it can be helpful in this case for diagnosis. However, it is undeniable that renal biopsy could have been avoided if MM had been listed as the differential diagnosis in this case.

In our case, the dissociation of total protein and albumin was not prominent, serum calcium was not elevated, and the patient was older and acutely ill. These atypical clinical presentations made it difficult to differentiate the diagnoses. One reason for this may be that the patient had an IgD-type MM. In our hospital, IgD is not routinely measured by serum immunoelectrophoresis, so we missed it. IgD MM is very rare, accounting for only $2 \%$ of all MM cases and clinical symptoms are often uncommon. Of the IgD MM cases, $82 \%$ had renal impairment, $37 \%$ had hypercalcemia, and the total serum protein averages were $6.8 \mathrm{~g} / \mathrm{dL}$ [14]. As aging societies progress, the number of older patients with various complications is likely to increase. In this case, the patient originally had osteoporosis and was receiving bisphosphonates. This may have masked the hypercalcemia that should have occurred in MM. In this context, we should consider the ADLs and the possibility of treatment even in persons of advanced years. We should provide appropriate scrutiny and treatment for renal disorders without falling into the category of ageism. Considering the possibility of inadequate investigation of chronic renal failure in older persons due to ageism, clinicians should provide the appropriate diagnosis and treatments for these patients.

The pathology behind cast nephropathy involves immunoglobulin light chains, which are originally mostly reabsorbed by the proximal tubules. These are produced in large quantities, as in MM, and exceed the capacity of the proximal tubules to process them. In the distal tubules and collecting ducts in the kidneys, these particles aggregate to form cylindrical casts. There are two hypotheses regarding the mechanism of the acute onset of severe renal failure in this case. First, there may have been an event in the background that significantly reduced the reabsorption capacity of immunoglobulin light chains in the proximal tubules. Second, the production of immunoglobulin light chains increased rapidly and progressed gradually. However, it suddenly manifested when the threshold was exceeded. These pathological conditions were also observed in the present case. These conditions may have occurred simultaneously. Factors that promote cast formation include dehydration, infection, hypercalcemia, contrast media, non-steroidal anti-inflammatory drugs (NSAIDs), and diuretics. Although there were no findings of dehydration or infection, in this case, the use of celecoxib was a suspected drug. This may have had a significant impact on renal damage in this case. NSAIDs suppress vasodilation by inhibiting the production of prostaglandins, resulting in pre-renal damage due to decreased renal blood flow. Although there is less risk of gastrointestinal damage and bleeding with COX-2 selective inhibitors, renal damage is thought to occur in the same manner as with nonselective NSAIDs. Caution is required with the use of these agents [15]. There are also data showing that $20-30 \%$ of patients with MM have renal failure at diagnosis, 3-9\% of newly diagnosed patients with MM will have severe renal impairment requiring dialysis, and $70 \%$ of patients requiring dialysis will have cast nephropathy. It is estimated that $70 \%$ of patients requiring dialysis have cast nephropathy [16]. Therefore, it is estimated that a small percentage of patients develop cast nephropathy as acute-onset kidney injury. The mechanism is thought to be a rapid increase in immunoglobulin short-chain production due to alterations in MM disease [16]. In our case, the creatinine level gradually worsened in one year. The fact that the disease progressed gradually and worsened rapidly within a month suggests that these pathological conditions were in place. It is necessary for clinicians to always consider the diseases behind the rapid deterioration of renal function in older patients. They must be aware of the exacerbation of the disease and the possibility that drug use may further aggravate the condition.

\section{Conclusions}

It is important to differentiate cast nephropathy from advanced renal failure among older adults, even if it is an acute clinical course. Rapid progression of cast nephropathy can be caused by the accumulation of short immunoglobulin chains through various predisposing factors, as in this case. In particular, older patients tend to have multiple comorbidities and take various medications. This can complicate the pathophysiology and make the clinical presentation uncommon. In this situation, a pathological biopsy is important as a decisive factor in the differential diagnosis. The indications for biopsy should be carefully considered, even 
in persons of advanced years. Appropriate scrutiny with MM in the differential diagnosis can avoid unnecessary renal biopsy. Older patients with acutely advanced renal failure should be investigated considering the possibility of MM, even if the presentation is atypical.

\section{Additional Information \\ Disclosures}

Human subjects: Consent was obtained or waived by all participants in this study. Conflicts of interest: In compliance with the ICMJE uniform disclosure form, all authors declare the following: Payment/services info: All authors have declared that no financial support was received from any organization for the submitted work. Financial relationships: All authors have declared that they have no financial relationships at present or within the previous three years with any organizations that might have an interest in the submitted work. Other relationships: All authors have declared that there are no other relationships or activities that could appear to have influenced the submitted work.

\section{Acknowledgements}

We would like to thank Editage (www.editage.com) for English language editing.

\section{References}

1. Yasushi T: Renal failure in multiple myeloma [Article in Japanese] . Internal Med. 2011, 108:282-6. 10.15106/J00974.2011312142

2. Kyle RA, Remstein ED, Therneau TM, et al.: Clinical course and prognosis of smoldering (asymptomatic) multiple myeloma. N Engl J Med. 2007, 356:2582-90. 10.1056/NEJMoa070389

3. Royal V, Leung N, Troyanov S, et al.: Clinicopathologic predictors of renal outcomes in light chain cast nephropathy: a multicenter retrospective study. Blood. 2020, 135:1833-46. 10.1182/blood.2019003807

4. Haas M, Spargo BH, Wit EJ, Meehan SM: Etiologies and outcome of acute renal insufficiency in older adults: a renal biopsy study of 259 cases. Am J Kidney Dis. 2000, 35:433-47. 10.1016/s0272-6386(00)70196-X

5. Kohli HS, Jairam A, Bhat A, Sud K, Jha V, Gupta KL, Sakhuja V: Safety of kidney biopsy in elderly: a prospective study. Int Urol Nephrol. 2006, 38:815-20. 10.1007/s11255-006-0088-0

6. Uezono S, Hara S, Sato Y, et al.: Renal biopsy in elderly patients: a clinicopathological analysis . Ren Fail. 2006, 28:549-55. 10.1080/08860220600840165

7. Harmankaya O, Okuturlar Y, Kocoglu H, et al.: Renal biopsy in the elderly: a single-center experience . Int Urol Nephrol. 2015, 47:1397-401. 10.1007/s11255-015-1035-8

8. Moutzouris DA, Herlitz L, Appel GB, Markowitz GS, Freudenthal B, Radhakrishnan J, D'Agati VD: Renal biopsy in the very elderly. Clin J Am Soc Nephrol. 2009, 4:1073-82. 10.2215/CJN.00990209

9. Abdel-Kader K, Palevsky PM: Acute kidney injury in the elderly . Clin Geriatr Med. 2009, 25:331-58. 10.1016/j.cger.2009.04.001

10. Nair R, Bell JM, Walker PD: Renal biopsy in patients aged 80 years and older . Am J Kidney Dis. 2004, 44:61826. 10.1053/j.ajkd.2004.05.044

11. Dhaun N, Bellamy CO, Cattran DC, Kluth DC: Utility of renal biopsy in the clinical management of renal disease. Kidney Int. 2014, 85:1039-48. 10.1038/ki.2013.512

12. Evidence-based practice guideline for the treatment of CKD. Japanese Society of Nephrology . (2018). Accessed: October 12, 2021: https://jsn.or.jp/journal/document/60_8/1037-1193.pdf.

13. Kidney Biopsy Guidebook 2020. Japanese Society of Nephrology . (2020). Accessed: October 12, 2021 https://cdn.jsn.or.jp/data/kb_guide_2020.pdf.

14. Djidjik R, Lounici Y, Chergeulaïne K, et al.: IgD multiple myeloma: clinical, biological features and prognostic value of the serum free light chain assay. Pathol Biol (Paris). 2015, 63:210-4. 10.1016/j.patbio.2015.06.002

15. Gooch K, Culleton BF, Manns BJ, et al.: NSAID use and progression of chronic kidney disease . Am J Med. 2007, 120:280.e1-7. 10.1016/j.amjmed.2006.02.015

16. Szabo AG, Thorsen J, Iversen KF, et al.: Clinically-suspected cast nephropathy: a retrospective, national, real-world study. Am J Hematol. 2020, 95:1352-60. 10.1002/ajh.25959 